\title{
Komunikasi Matematika Siswa Kelas V Sekolah Dasar Pada Materi Volume Kubus Dan Balok
}

\author{
Dewi Kristika Findia Ning Tyas \\ Program Studi Pendidikan Matematika, FKIP, Universitas Cenderawasih \\ Email: dewi.findianingtyas@fkip.uncen.ac.id
}

\begin{abstract}
Abstrak. Tujuan penelitian ini adalah mendeskripsikan kemampuan komunikasi matematika tulis siswa kelas $\mathrm{V}$ sekolah dasar pada materi volume kubus dan balok. Berdasarkan tujuan penelitian, maka penelitian ini termasuk dalam penelitian deskriptif dengan menggunakan pendekatan kualitatif. Dalam menentukan subjek penelitian digunakan teknik purposive sampling (pengambilan subjek berdasarkan tujuan) dengan menetapkan kriteria pemilihan subjek. Kriteria subjek dalam penelitian ini adalah 1) subjek kemapuan tinggi, sedang dan rendah;2) Subjek dapat mengemukakan pendapat secara lisan maupun tulisan; 3) Subjek merupakan peserta didik yang selalu aktif mengikuti pembelajaran matematika. adapun hasil penelitian yaitu: Siswa dengan kemampuan tinggi memenuhi semua indicator kemampuan komunikasi matematika tulis, sedangkan siswa dengan kemampuan sedang memenuhi semua indicator kemampuan komunikasi matematika tulis, namun jika melihat hasil pekerjaan siswa dengan kemampuan tinggi dan siswa dengan kemampuan sedang terdapat perbedaan dalam gaya penyampaian/menjelaskan, dimana lebih mudah memahami penjelasan subjek dengan kemampuan tinggi. Sedangkan subjek dengan kemampuan rendah tidak memenuhi semua indicator kemampuan komunikasi matematika tulis.
\end{abstract}

Kata Kunci: Komunikasi Matematika Siswa, Volume Kubus Dan Balok

\section{PENDAHULUAN}

Dewan Nasional Guru Matematika (NCTM) menetapkan 5 standar proses dalam pembelajaran matematika, salah satunya adalah komunikasi. Komunikasi diartikan sebagai:

Mathematical communication is a way of sharing ideas and clarifying understanding. Through communication, ideas become objects of reflection, refinement, discussion, and amendment. When students are challenged to communicate the results of their thinking to others orally or in writing, they learn to be clear, convincing, and precise in their use of mathematical language. Explanations should include mathematical arguments and rationales, not just procedural descriptions or summaries. Listening to others' explanations gives students opportunities to develop their own understandings. Conversations in which mathematical ideas are explored from multiple perspectives help the participants sharpen their thinking and make connections (NCTM, 2000).

Berdasarkan definisi yang diberikan NCTM maka komunikasi matematika adalah cara berbagi ide dan memperjelas pemahaman. Menurut Depdiknas, (2004) kemampuan komunikasi matematika merupakan kesanggupan/kecakapan seorang siswa untuk dapat menyatakan dan menafsirkan gagasan matematika secara lisan, tertulis, atau mendemonstrasikan apa yang ada dalam soal matematika. Sedangkan menurut (Triana, 2019) kemampuan komunikasi matematika adalah kemampuan untuk mendemonstrasikan gagasan dan simbol matematika baik secara lisan maupun tulisan, gambar, atau diagram.

Berdasarkan definisi komunikasi matematika di atas maka komunikasi matematika menjadi salah satu kunci keberhasilan pembelajaran matematika di dalam kelas. Sependapat dengan (Johar, dkk., 2018) komunikasi merupakan hal yang mendasar dalam pembelajaran matematika. Lebih lanjut, Baroody's (Rosita, dkk., 2019 ), ada dua alasan penting mengapa komunikasi matematika menjadi salah satu fokus pembelajaran matematika. Pertama, matematika pada dasarnya adalah bahasa untuk matematika itu sendiri. Kedua, pembelajaran matematika merupakan kegiatan sosial yang melibatkan minimal dua pihak, yaitu guru dan siswa.

Kemampuan komunikasi matematika siswa yang baik dapat ditunjukkan dengan mudahnya teman atau guru dalam memahami apa yang disampaikan, sehingga tidak memerlukan penjelasan lanjutan. Senada dengan 
pernyataan tersebut menurut (Setiyani, 2020) komunikasi adalah cara untuk menyelesaikan dan memperjelas masalah melalui pemahaman. Menurut (Sudia, 2020) keterampilan komunikasi sebagai cara bertukar pikiran atau mengungkapkan gagasan sehingga gagasan tersebut dapat diperjelas dan dikembangkan, untuk pengetahuan baru dalam matematika.

Guru harus memperhatikan dan dapat mengembangkan kemampuan komunikasi matematika siswa guna peningkatan kwalitas pembelajaran. Menurut (Rohid, 2019) komunikasi merupakan faktor penting dalam meningkatkan kualitas belajar dan pemahaman siswa pada mata pelajaran matematika. Dengan memberikan tes salah satunya, guru dapat melihat kemampuan komunikasi matematika siswa, pada penelitian ini yaitu kemampuan komunikasi matematika tulis.

Materi volume kubus dan balok selalu ditemui siswa di semua jenjang pendidikan. Sehingga sangat penting bagi siswa untuk dapat mengkomunikasikan dalam aktivitas belajar. Selain itu materi volume kubus dan balok sangat erat kaitannya dalam kehidupan sehari-hari.

Adapun Indikator kemampuan komunikasi matematika tulis yaitu: (1) menuliskan apa yang diketahui dan ditanyakan; (2) Menuliskan operasi hitung yang sesuai, (3) Menafsirkan solusi yang diperoleh ataupun menggunakan representasi meyeluruh untuk menyatakan konsep matematika dan solusinya, (4) Menggunakan tabel, gambar, model dan lainlain untuk menyampaikan penjelasan, (5) Kemampuan menjelaskan kesimpulan yang diperoleh (Syafina \& Pujiastuti, 2015).

\section{METODE PENELITIAN}

Tujuan penelitian ini adalah
mendeskripsikan kemampuan komunikasi
matematika tulis siswa kelas V sekolah dasar
pada materi volume kubus dan balok.
Berdasarkan tujuan penelitian, maka penelitian
ini termasuk dalam penelitian deskriptif dengan
menggunakan pendekatan kualitatif. Menurut
Arikunto (2013: 234) bahwa penelitian
deskriptif merupakan penelitian yang bertujuan

untuk mengumpulkan informasi mengenai status suatu gejala yang ada, yaitu keadaan gejala menurut apa adanya pada saat penelitian dilakukan. Dalam menentukan subjek penelitian digunakan teknik purposive sampling (pengambilan subjek berdasarkan tujuan) dengan menetapkan kriteria pemilihan subjek. Menurut Sugiyono (2015:300), "purposive sampling" adalah teknik penentuan sampel dengan kriteria-kriteria tertentu". Kriteria subjek dalam penelitian ini adalah 1) subjek kemapuan tinggi, sedang dan rendah; 2) Subjek dapat mengemukakan pendapat secara lisan maupun tulisan; 3) Subjek merupakan peserta didik yang selalu aktif mengikuti pembelajaran matematika. Instrumen penelitian yang akan digunakan dalam penelitian ini adalah: 1) Instrumen utama, menurut (Sugiyono, 2015), dalam penelitian kualitatif instrumen atau alat penelitian utama yaitu peneliti sendiri dan tidak dapat digantikan dengan instrumen lain; 2) Instrumen pendukung, instrumen pendukung yang digunakan dalam penelitian ini yaitu lembar tes uraian. Lembar tes merupakan lembar yang berisi soal pada materi volume kubus dan balok masing-masing satu soal, sehingga jumlah soal keseluruhan yaitu dua soal. Teknik pengumpulan data dalam penelitian ini yaitu tes. Tes yang digunakan adalah bentuk tes tertulis. Tes tertulis adalah sekumpulan item pertanyaan dan atau pertanyaan yang direncanakan oleh peneliti secara sistematis, guna memperoleh informasi tentang subjek penelitian (Sukardi, 2015). Menurut (Sugiyono, 2015), analisis data adalah proses mencari dan menyusun secara sistematis data yang diperoleh dari hasil wawancara, catatan lapangan, dan dokumentasi sehingga mudah di pahami oleh diri sendiri maupun orang lain. Analisis data dalam penelitian kualitatif dilakukan sejak sebelum memasuki lapangan, selama dilapangan dan setelah selesai di lapangan. Menurut (Sugiyono, 2015), terdapat tiga tahapan menganalisis data dalam penelitian kualitatif, yaitu: 1) Reduksi data; 2) Penyajian data; 3) Menarik simpulan atau verifikasi. 


\section{HASIL PENELITIAN}

Setelah instrumen pendukung yaitu lembar tes uraian valid, soal dapat diberikan kepada siswa.

Adapun soal yang diberikan yaitu:

1. Fidelita memiliki kotak perhiasan besar berukuran $35 \mathrm{~cm}$ x $15 \mathrm{~cm}$ x $10 \mathrm{~cm}$. Dalam kotak perhiasan besar tersebut berisi kotakkotak perhiasan kecil berukuran $5 \mathrm{~cm}$ x $5 \mathrm{~cm}$ $\mathrm{x} 5 \mathrm{~cm}$. tiap kotak perhiasan kecil berisi satu set perhiasan. Ada berapa kotak perhiasan kecil di dalam kotak perhiasan besar?

2. Gavarel memiliki 2 kolam lele yang berukuran sama yaitu $3 \mathrm{~m}$ x $2 \mathrm{~m}$ x $1 \mathrm{~m}$. Kolam lele pertama akan di isi air setengah saja, kemudian kolam kedua akan di isi air sepertiga saja. Berapakah volume air yang dibutuhkan (dalam liter)?

Selanjutnya, dipilih subjek berdasarkan kriteria yang telah ditetapkan. Hasil pekerjaan subjek kemudian dianalisis untuk melihat kemampuan komunikasi matematika tulis siswa. Adapun hasil analisis sebagai berikut:

Subjek 1

Soal no 1

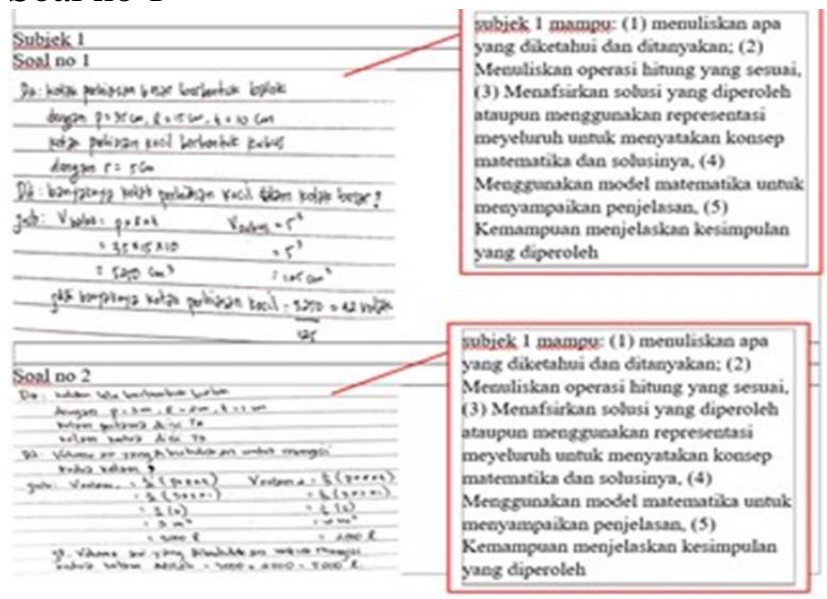

Soal no 2

Subjek 2 Soal no 1

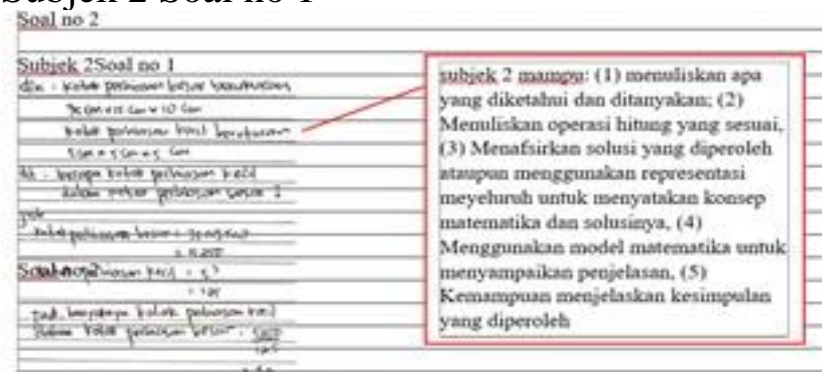

Soal no 2

\begin{tabular}{|c|c|}
\hline & \multirow{12}{*}{ 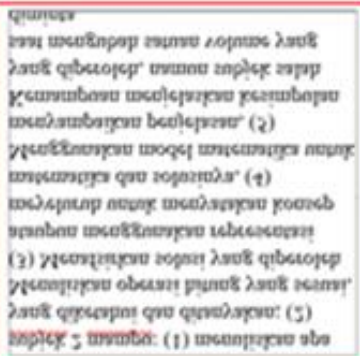 } \\
\hline 200 & \\
\hline 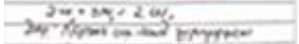 & \\
\hline$p<\omega_{0}=x_{1}$ & \\
\hline 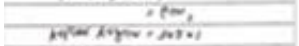 & \\
\hline 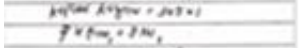 & \\
\hline 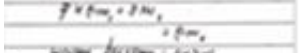 & \\
\hline 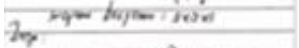 & \\
\hline 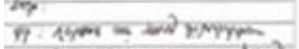 & \\
\hline 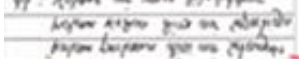 & \\
\hline jonatim & \\
\hline 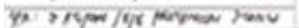 & \\
\hline
\end{tabular}

Subjek 3

Soal no 1

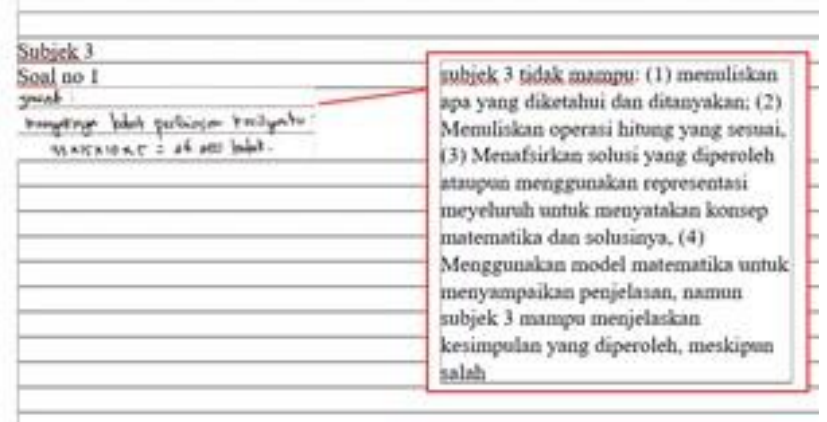

Soal no 2

\begin{tabular}{|c|c|}
\hline Soal no 2 & \\
\hline rext: & subiek 3 tidak mampu (1) menuliskan \\
\hline Volume kolom lele: $3 \times 2 \times 1=6 \mathrm{~m}$ & apa yang diketahui dan ditanyakan: $(2)$ \\
\hline 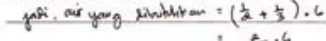 & Menuliskan operasi hitung yang sesuai. \\
\hline & (3) Menafsirkan solusi yang diperoleh \\
\hline & ataupun menggunakan representasi \\
\hline & meyeluruh untuk menyatakan konsep \\
\hline & matematika dan solusinya, (4) \\
\hline & Menggunakan model matematika untuk \\
\hline & menyampaikan penjelasan, namun \\
\hline & subjek 3 mampu menjelaskan \\
\hline & kesimpulan yang diperoleh, meskipun \\
\hline
\end{tabular}

\section{PEMBAHASAN}

Kemampuan komunikasi matematika tulis subjek 1 baik, semua indicator kemampuan komunikasi matematika tulis terpenuhi. Demikian juga dengan subjek 2 hampir semua indicator kemampuan komunikasi terpenuhi, hanya saja subjek 2 melakukan kesalahan pada saat mengubah satuan volum dari $\mathrm{m}^{3}$ menjadi liter. Sedangkan subjek 3 kemampuan komunikasi matematikanya rendah, dimana tidak semua indicator kemampuan komunikasi matematika terpenuhi.

Jika melihat hasil pekerjaan subjek 1 kita dapat memahami bagaimana langkah penyelesaian yang digunakan, sehingga dapat 
dikatakan kemampuan komunikasi matematika tulis subjek 1 dengan kemampuan tinggi adalah baik. Hal tersebut sesuai dengan (Setiyani, 2020) yang mengatakan kemampuan komunikasi matematika siswa yang baik dapat ditunjukkan dengan mudahnya teman atau guru dalam memahami apa yang disampaikan, sehingga tidak memerlukan penjelasan lanjutan. Untuk subjek 2 dengan kemampuan sedang, jika melihat hasil pekerjaannya sudah mampu menuliskan penyelesaian menggunakan bahasanya sendiri, namun penjelasan subjek 1 lebih mudah dipahami dibandingkan dengan subjek 2 meskipun sudah memenuhi semua indicator kemampuan komunikasi matematika tulis. Kemudian subjek 2 juga melakukan kesalahan dalam mengubah satuan volum. Jika melihat hasil pekerjaan Subjek 3 dengan kemampuan rendah dapat dikatakan kemampuan komunikasi matematika rendah, karena tidak memenuhi semua indicator kemmapuan komunikasi matematika tulis.

\section{SIMPULAN}

Siswa dengan kemampuan tinggi memenuhi semua indicator kemampuan komunikasi matematika tulis, sedangkan siswa dengan kemampuan sedang memenuhi semua indicator kemampuan komunikasi matematika tulis, namun jika melihat hasil pekerjaan siswa dengan kemampuan tinggi dan siswa dengan kemampuan sedang terdapat perbedaan dalam gaya penyampaian/menjelaskan, dimana lebih mudah memahami penjelasan subjek dengan kemampuan tinggi. Sedangkan subjek dengan kemampuan rendah tidak memenuhi semua indicator kemampuan komunikasi matematika tulis.

\section{DAFTAR PUSTAKA}

Arikunto, S. 2013. Prosedur Penelitian: Suatu Pendekatan Praktik. Jakarta: Rineka Cipta.

Depdiknas. 2004. Peraturan Dirjen Dikdasmen No. 506/C/PP/2004 tanggal 11 November 2004 tentang Penilaian Perkembangan Anak Didik Sekolah
Menengah Pertama (SMP). Jakarta: Ditjen Dikdasmen Depdiknas.

Johar, R., Junita, E., \& Saminan, S. (2018). Students' Mathematical Communication Ability and SelfEfficacy Using Team Quiz Learning Model. International Journal on Emerging Mathematics Education, 2(2), 203. https://doi.org/10.12928/ijeme.v2i2.87 02

National Council of Teacher Mathematics (NCTM). 2000. Principles and Standards for School Mathematics. Reston Virginia: NCTM.

Rohid, N., Suryaman, S., \& Rusmawati, R. D. (2019). Students' Mathematical Communication Skills (MCS) in Solving Mathematics Problems: A Case in Indonesian Context. Anatolian Journal of Education, 4(2), 19-30. https://doi.org/10.29333/aje.2019.423a

Rosita, C. D., Nopriana, T., \& Silvia, I. (2019). Design of Learning Materials on Circle Based on Mathematical Communication. Infinity Journal, 8(1), 87.

https://doi.org/10.22460/infinity.v8i1.p 87-98

Setiyani, Putri, D. P., Ferdianto, F., \& Fauji, S. H. (2020). Designing a digital teaching module based on mathematical communication in relation and function. Journal on Mathematics Education, $\quad 11(2), \quad 223-236$. https://doi.org/10.22342/jme.11.2.7320 $.223-236$

Sudia, M., Puspita, A., \& Muhammad, A. (2020). A PBL Model to Improve Students Mathematical Communication Abilities: SelfRegulated Learning. 12(7), 537-554.

Sugiyono. 2015. Metode penelitian pendidikan. Bandung: Alfabeta.

Sukardi, H.M. 2015. Evaluasi Pendidikan Prinsip dan Operasionalnya. Jakarta: Bumi Aksara 
Syafina, V., \& Pujiastuti, H. (2015). Analisis Kemampuan Komunikasi Matematis Siswa Pada Materi SPLDV. Maju, 7(2), 118-125.

Triana, M., Zubainur, C. M., \& Bahrun, B. (2019). Students' Mathematical Communication Ability through the Brain-Based Learning Approach using Autograph. JRAMathEdu (Journal of Research and Advances in Mathematics Education), 4(1), 1-10. https://doi.org/10.23917/jramathedu.v4 i1.6972 